\title{
Operators' Capability and Facilities Availability for Repair and Maintenance of Small Tractors in Riau Province, Indonesia: A Case Study
}

\author{
Ujang Paman (Corresponding author) \\ The United Graduate School of Agricultural Science, Kagoshima University, Japan \\ Permanent address: Department of Agricultural Economics, Faculty of Agriculture, Riau Islamic University \\ Jl. Kaharuddin Nasution No. 113 Perhentian Marpoyan Pekanbaru 28284 Riau, Indonesia
}

Tel: 62-761-704-7726_E-mail: u_paman@yahoo.com

\author{
Susumu Uchida \\ Department of Agricultural Sciences, Saga University \\ 1 Honjo Machi, Saga 840-8502, Japan \\ Shigeki Inaba \\ Department of Agricultural Sciences, Saga University \\ 1 Honjo Machi, Saga 840-8502, Japan
}

Received: July 13, 2011

Accepted: July 25, $2011 \quad$ Online Published: December 29, 2011

doi:10.5539/jas.v4n3p71

URL: http://dx.doi.org/10.5539/jas.v4n3p71

\begin{abstract}
This paper presents the capability of tractor operators in performing repair and maintenance of small tractors, the availability of service and repair facilities at the farm level, and the manner of the operators in maintaining their tractors. Data are based on field visits and interviews with 65 tractor operators from 6 villages collected in three regencies of Riau Province. The results show that most operators lack the technical skill to service and repair tractors due to insufficient training, specific education, and work experience. Inadequate repair and maintenance facilities, such as workshops, mechanics, and spare part depots cause delays in repair work and raise the price of spare parts in the survey areas. Farmers do not keep accurate service records and most of them disregard proper maintenance and service of their tractors, such as changing engine oil without following the manufacturer's recommendations. Provincial governments should provide training facilities and a program to improve the technical knowledge and skills of the operators and local mechanics. Repair and maintenance facilities should be established in village areas to guarantee timely repair in case of breakdowns and to make spare parts available at low price. The operators should keep service records accurately and adhere to maintenance and service schedules according to the manufacturer's instructions. They should also be encouraged to properly service and maintain their tractors.
\end{abstract}

Keywords: Operators' capability, Facilities availability, Repair and maintenance, Small tractors

\section{Introduction}

Tractor ownership represents a considerable amount of capital investment in agricultural production. For modern farming, for example, it makes up as much as $40 \%$ of the total investment (Henderson and Guericke, 1985). The success of the investment depends greatly on operating costs, which, in turn, are influenced greatly by the quality of repair and maintenance. Rahmoo et al. (1979) stated that the economic benefits from a tractor depend upon the efficient manner of its use. Therefore, tractor should be maintained correctly to ensure effectively working for a long period without any breakdown and thus provide a much benefit to its owners. A tractor that breaks down and must be prematurely replaced incurs large expenses and wastes the investment. As an example, in 
developing countries approximately $53 \%$ of total machine expenses have gone to repair machine breakdown as compared to $8 \%$ in developed countries (Inns, 1978).

In Indonesia, small tractors (also known as "power tillers") are the most popular farm machinery used in food crop fields, especially in paddy fields, which are dominated by small-scale farms and subsistence in production. The tractors are generally used for land preparation with very little use in other farm operations (Salokhe and Hendriadi, 1995). In Riau province, of the 811 tractors available on farm in 2006, about $95 \%$ are small tractors (Food Crop Service of Riau Province, 2007). They mostly operate once a year under single cropping system for both rain-fed paddy field and semi-technical irrigation system areas. In some cases, the tractors can operate twice a year under double cropping system in the area under good irrigation system.

The use of tractors instead of hand tools and animal-drawn implements requires special management ability and skills as well as adequate service support facilities. However, the use of the farm machines in Riau Province has increased considerably without a corresponding program for training farmers and agricultural extension officials, and without sufficient service and maintenance facilities to support efficient and economic tractor use at the farm level. Under such circumstances, the average life of a machine therefore becomes shorter because it is difficult for farmers to repair tractors when they break down. Tractor breakdown was found to be one of the main problems in hand tractors operation in Riau Province (Paman et al., 2007).

A number of studies have reported the causes of a high breakdown frequency and a high repair rate (Kolawole, 1972; Inns, 1978; Bukhari, 1982; Kuyembeh, 1982; Jacob and Harrell, 1983; Bukhari et al., 1984; Aneke, 1994; Adekoya and Otono; 1990; FAO, 1992; Babatunde, 1996; Paman et al, 2007). The authors found that unskilled operators, poor operation and maintenance practices, and lack of spare parts were the main contributing factors. Untrained operator, for example, was found to be a major cause of high repair and maintenance costs in Pakistan (Bukhari, 1982), and improper handling by tractor operators caused frequent breakdowns in Nigeria (Kolawole, 1972). Furthermore, failure of the regular supply of replacement parts for machinery and equipment in developing counties has often led to large numbers of agricultural machines remaining unserviceable for long periods (FAO, 1992).

Therefore, operators and mechanics should ideally be well trained and furnished with suitable maintenance and repair facilities. The manner in which the tractor is treated is also an essential factor to keep it in good operating condition. The purpose of the present study is to recognize the capability of tractor operators in performing repair and maintenance of small tractors, to identify the availability of service and repair facilities at the farm level, and to evaluate the manner of the operators in maintaining their tractors.

\section{Materials and Methods}

A survey was conducted in three regencies in Riau Province, namely Kuantan Sengingi, Rokan Hulu, and Siak. They are located $183 \mathrm{~km}$ west, $175 \mathrm{~km}$ north, and $120 \mathrm{~km}$ south, respectively, of Pekanbaru, the capital of Riau Province. These regencies were chosen for survey locations because of their high tractor uses and the importance of rice production which uses predominantly small tractors to mechanize land preparation. A total of 65 tractors from six villages - two villages from each regency - were selected randomly from lists of tractors in each village. The tractor operators (also farmers) were personally interviewed through home or workplace visits in 2005-06. Data were gathered from records and through verbal information on pre-tested questionnaires in cases where farmer records were absent. Agricultural extension officers, local repair shop workers, and spare part shop owners were also asked to provide supplementary information. The tractor owners or operators were asked detailed questions covering repair and maintenance, daily checks, regular services, engine oil or lubricant service interval, fuel and lubricant consumptions, cleaning, greasing, and methods of protecting tractors during fieldwork and off-season. The data were tabulated and then analyzed using simple descriptive techniques including percentages and means.

\section{Results and Discussion}

\subsection{General Information}

Based on the survey, it was found that eighty-five percent of the tractors were operated by two operators and the rest by a single operator. The total number of operators was 115 persons and about $35 \%$ of them were beginner. The largest number of operators was seasonal hired labors (48\%), followed by relatives (37\%) and owners (15\%). The operators varied in age (ranging from 17 to 57 years), educational level (ranging from no formal education to senior high school graduate), and work experience (ranging from 1 to 23 years). 


\subsection{Technical Skill of Operators}

The results listed in Table 1 indicate that most operators can perform only the easiest levels of service and repairs. For instance, about $93 \%$ of the operators can perform minor services or adjustments on belts and clutch components. However, it was found that about $90 \%$ of the tractor operators have received no training or supervised experience in operating and maintaining tractors. Operators commonly learn mostly from other operators or are taught by family members. Most of the operators also have little experience (less than 5 years) in tractor operation and little education (illiterate and elementary school level). Illiteracy and the completion of fewer educational levels limit the ability of operators to study the operator's manual and to understand all the instructions.

\section{$<$ Table 1>}

Few operators had only the skill to perform major repairs such as repairing a piston ring, piston, connecting rod, and metal. These operators are commonly the ones who are most experienced; in a few cases, these experienced operators can perform tractor overhaul. Discussion with owners revealed that operators with five years or more work experience can perform major repairs or overhauls. Additionally, approximately $10 \%$ of operators have received government-sponsored short training courses. Service and repair needs that lie beyond the ability of tractor operators were performed by local mechanics; however, these mechanics have insufficient knowledge and skills to repair tractors. Qualified service technicians are generally clustered at tractor workshops and dealers in the city. In most major repair cases, therefore, the best current solution is to drive the tractor over long distances to the regency capital and to dealers in the province capital, Pekanbaru, for repair.

It is clear that the poor technical knowledge and skills of the operators and local mechanics are due mainly to an inadequate training program conducted by the provincial government. There is no institution provided by the government and other organizations for training tractor operators and mechanics in the Province. The existing training program is performed outside of the Riau Province and is attended only by few farmers. Additionally, dealers and their agents do not provide adequate training related to tractor repair and handling at the time of sale.

\subsection{Maintenance and Repair Facilities}

Maintenance and repair facilities are not yet well developed in Riau province. Table 2 shows that very few repair and welding shops are available in each regency. Existing shops are divided into government and private repair shops, which receive financial support from the food crop service of the province. Most of the facilities are located in the regency capital, while tractors commonly operate in the village area. In Siak regency, one of the areas surveyed, workshops are available $26 \mathrm{~km}$ from the village. In Rokan Hulu regency, the nearest repair shops are more than $20 \mathrm{~km}$ away. Consequently, most farmers frequently feel frustrated when faced with serious breakdowns due to inadequate repair facilities available in their village areas.

$<$ Table 2>

There are some private repair shops, specifically for truck and car repairs and scattered throughout the village area, that offer a wide range of services. However, most of them lack appropriate tools and suitably skilled mechanics and do not stock sufficient parts, especially for repairing tractors. Therefore, disabled tractors frequently must be hauled by truck and trader cars to repair shops in the city and even to dealers in the province capital for repair. It was observed that most of the repair shops in the city apply inadequate tools and poorly skilled mechanics to repairs that require specialized tools and a high skill level. These conditions increase repair cost and time. Sometimes transportation is not possible, which limits repair options and also increases cost. In order to reduce transportation, distance, and costs, repair shops should ideally be located close to the village area.

Apart from inadequate repair shops, there are hardly any shops selling spare parts in the village or district area. Most spare parts are available at the shops in regency capital or at dealers in the province capital (Table 3). Interviews with shop owners revealed that they only stock the best-selling spare parts. Many farmers have no access to the dealers, where are commonly located in the province capital, to procure spare parts. Spare parts not available at the shops can be ordered, but there is no guarantee when these orders will be delivered. The shop owners also stated that spare parts are sometimes difficult to find, particularly for some types and models.

$<$ Table 3>

Table 3 also compares the price of spare parts at the shops in the village area and in the regency capital compared to dealers in the province capital, Pekanbaru. As a consequence, farmers had to purchase spare parts, which were more expensive at a range from $13 \%$ to $20 \%$ at the shop in regency capital than at dealers, while the price was $25 \%$ higher at shops in the village area. The long distance and poor road infrastructure limited access to the city centers and consequently resulted in high transportation and spare parts costs in the village areas. 
In addition, the limited availability of gas stations in the vicinity of villages leads to increased fuel price. Most farmers purchased fuel from suppliers in the village area to about $25 \%$ higher than at the gas station. Meanwhile, the suppliers obtain diesel fuel from gas stations $25-40 \mathrm{~km}$ away. The government subsidizes the diesel fuel sold at the gas station, so the price is cheaper than at fuel suppliers who purchase at the same place. Farmers commonly had no container to stock large amounts of fuel and buy only 5 to 10 liters at one time as a result.

$<$ Table 4>

Of the 125 breakdown cases, approximately $76 \%$ required minor repair, and the remaining $24 \%$ was in the major repair category. Table 4 shows that most minor repairs could be performed on schedule, while about $11 \%$ and $5 \%$ cases were delayed due to inadequate repair and maintenance facilities and financial difficulty of the farmers, respectively. On the other hand, about $60 \%$ of the major repairs were delayed because of the lack of spare parts, workshops and mechanics in the village areas, while about $33 \%$ were due to financial difficulty of the farmers. Only about $7 \%$ of the major repairs could be performed according to schedule. Accordingly, some severely damaged tractors remained unserviceable for at least one crop season due to either the lack of spare parts or financial difficulty.

\subsection{Daily Checks and Service Schedule}

Tractor operators are largely responsible for the daily checks and service of tractors. Service and maintenance practiced by the operators were investigated on the subject of daily checks and engine oil changes. Table 5 shows that only a minority of farmers performed maintenance on a regular basis. Hose leaks were maintained the most frequently by the farmers, while air cleaners were maintained the least frequently. Other maintenance targets, such as oil levels, belt tension, fuel sediment bowls, and lubrication were only occasionally checked. Maintenance before failure is a key part of safe and efficient operation in the field (Butterworth, 1984). For example, low oil levels reduce the degree of lubrication and thus cause premature failure (Jain and Rai, 1980). However, most farmers are accustomed to sending a tractor to a repair shop for service only after it has limited functionality or has stopped operating completely.

$<$ Table 5>

Not all records of the servicing periods of the tractors could be known, so some service schedules were recalled from memory in cases where the farmers did not maintain records at all. Typical intervals between engine oil changes are presented in Table 6. Most farmers (90\%) did not rely on the operator's manual for service interval schedules and only $10 \%$ of them followed the manual's instructions thoroughly. Additionally, farmers often use unauthorized sources for service interval schedules. According to Paman et al. (2007), they generally depend on past experience, manual test of oil viscosity, and recommendations from other farmers. A survey conducted by Wertz et al. (1990) in Lancaster County, Nebraska, documented that $42 \%$ of the farmers ignored the advice given in the manuals. The different distribution of maintenance practice between the two sets of operators may reflect differences in skill and education.

Referring to Table 6 , it is seen that forty-three percent of farmers scheduled service more frequently than recommended, while $47 \%$ of farmers waited longer than the scheduled interval between service events. However, the appropriate service interval time can be reduced by one-half where tractors are operated in extremely dusty or dirty conditions (Jacobs and Harrell, 1983). More frequent service is, of course, more costly, but the additional cost is expected to correspond to reduced engine trouble. The results imply that the operator attitude toward good maintenance practices is very poor.

$<$ Table 6>

Oil prices differ between brands, with imported oils being more expensive. The most popular brands used by the farmers are Pennzoil (20\% of samples), Mesran (35\%), Power plus (40\%) and others (5\%). Farmers were found to choose oil brands based on oil quality $(25 \%)$, availability $(35 \%)$, and price $(40 \%)$. Farmers commonly used SAE-40 for tractor engines with an average oil consumption of $0.04 \mathrm{l} / \mathrm{h}$. For transmission oil, farmers commonly used Rored with SAE-90 with an average consumption of $0,01 \mathrm{l} / \mathrm{h}$.

\subsection{Cleaning and Storing}

Most farmers cleaned the tractor engine at the end of the working day and the body and the implement at the end of the working season. It means that tractors are cleaned thoroughly (engine, body, and implement) only twice per year, which allowed rusting of the body, iron wheels, and nuts and bolts. Most of the farmers did not periodically lubricate high-friction parts during field operations and they were just greased at the beginning of the working season. 
Safety and distance from the house to the field are important considerations of farmers' decisions to shelter their tractors. About $47 \%$ of the farmers left their tractors in the field covered with plastic or under a tree, $40 \%$ brought back only the tractor engine and the remaining $13 \%$ conveyed the tractors home after each working season. During off-season, most farmers (40\%) stored the tractors in a shed; other farmers put them on the porch $(32 \%)$ or left them outdoors (27\%) (Table 7). Unavailability of the shed was the primarily reason for tractors being stored outdoors.

$<$ Table 7>

According to the survey, the lack of attention of some operators towards tractor care and maintenance was, in fact, caused not only by poor skill and knowledge, but also financial problems. Discussions with farmers revealed that most of their farms operate at a subsistence level of production and do not make enough profit. Such condition caused farmers difficult to perfom good maintenance of their tractors. Some farmers, for instance, must leave their tractors outdoors even when they know the consequences of such action.

\section{Conclusions and Recommendations}

The capability of the operators to service and repair tractors is very poor due to insufficient training, specific education, and work experience. Only $10 \%$ of the operators have received training in the proper operation, repair, and maintenance of tractors. Inadequate repair and maintenance facilities were found in the survey area. Consequently, about $60 \%$ of major repairs and $11 \%$ of minor ones can not be performed on schedule due to the lack of spare parts, workshops, and mechanics. In addition, inadequate spare part shops in the village areas raise the price of these parts. Farmers do not keep accurate service records and most of them pay little attention to daily checks, routine engine oil changes, and the need for periodic servicing. It is evident that about $90 \%$ of the farmers schedule engine oil changes without following the manufacturer's recommendation. Moreover, some farmers also do not perform proper care and maintenance on cleaning, greasing, and protecting/storing during working and off-season. Financial problems also make it difficult for farmers to provide dedicated maintenance facilities for sheltering tractors.

The recommendations made are summarized as follow:

1) Provincial government should provide training facilities and a program to improve the technical knowledge and skills of operators and local mechanics.

2) Repair and maintenance facilities, such as repair shops, spare parts shops, and local mechanics, should be established in the village areas to guarantee timely repair in case of breakdown along with spare parts available at low price.

3) Farmers should keep accurate service records and make service schedules in performing daily checks, periodic servicing, and oil changes according to manufacturer's instructions.

4) Farmers should be encouraged to perform good care and maintenance by cleaning, greasing, protecting, and storing tractors during the working season and off-season.

\section{References}

Adekoya, L. O, \& Otono, P. A. (1990). Repair and maintenance costs of agricultural tractors in Nigeria. Tropical Agriculture, Vol. 67(2): 119-122.

Aneke, D. O. (1994). A survey of farm power problem in Nigeria. Applied Engineering in Agriculture, Vol. 10(5): 623-626.

Babatunde, O. O. (1996). An appraisal of the problem of wheeled tractors used in Nigerian agriculture. Agricultural Mechanization in Asia, Africa and Latin America, Vol. 27(3): 23-26.

Bukhari, S. B. (1982). Evaluation of farmer's competence to maintain farm tractors. Agricultural Mechanization in Asia, Africa and Latin America, Winter Issue. 45-47.

Bukhari, S. B., Rajper, A. G., Soomro, M. S., \& Sawar, J. G. (1984). Status of Farm Mechanization Facilities in Khairpur, Pakistan. Agricultural Mechanization in Asia, Africa and Latin America, Vol. 15(1): 37-42.

Butterworth, B. (1984). Farm tractors: The case guide to tractor selection, operation, economic, and maintenance. E. \& F. N. Spon, London, (Chapter 8).

FAO. (1992). Agricultural engineering in development: guidelines for rebuilding replacement parts and assemblies. Agricultural Services Bulletin, 91, Rome. 106 p.

Food Crop Services of Riau Province. (2007). Data series of Food Crop of Riau Province. Pekanbaru, Indonesia. 
Henderson, H. D., \& Guericke, W. (1985). Economics of tractor operation in Swaziland. Agricultural Mechanization in Asia, Africa and Latin America. Vol. 16(4): 11-16.

Inns, F. M. (1978). Operational aspect of tractor use in developing countries: a case for the small tractor. The Agriculture Engineer, Summer Issue. 52-54.

Jacobs, C. O., \& Harrell, W. R. (1983). Agricultural Power and Machinery. McGraw-Hill, Inc. New York, (Chapter 10).

Jain, S. C., \& Rai, C. R. (1980). Tractor engine maintenance and repair. Tata McGraw-Hill Publishing Company Limited, New Delhi, (Chapter 7).

Kolawole, M. I. (1972). Economic aspects of tractor contracting operations in Western Nigeria. Journal Agricultural Engineering Research, Vol. 17: 289-294. http://dx.doi.org/10.1016/S0021-8634 (72)80033-7

Kuyembeh, N. G. (1982). Farm mechanization in Sierra Leone. Agricultural Mechanization in Asia, Africa and Latin America, Spring Issue. 71-76.

Paman, U., Uchida. S., Inaba, S., \& Kojima, T. (2007). A survey on causes of tractor breakdowns in Riau Province, Indonesia; a case study of small tractor operations. Applied Engineering in Agriculture, Vol. 23(1): $12-18$.

Rahmoo, A. A., Henderson, H. D., \& Thierstein, G. E. (1979). Costs of owning and operating tractors in Tharparkar District of Sind, Pakistan, Agricultural Mechanization in Asia, Autumn Issue. Vol. 10(4): 27-30.

Salokhe, V. M., \& Hendriadi, A. (1995). Power tiller industry in Indonesia. Agricultural Mechanization in Asia, Africa and Latin America, Vol. 26(4): 29-32.

Wertz, K., Grisno, R., \& Von Bargen, K. (1990). A survey of AG tractor service intervals - Part I. Applied Engineering in Agriculture, Vol. 6(5): 537-541.

Table 1. Skill ability of operators to service and repair tractors

\begin{tabular}{|l|c|c|l|c|r|}
\hline $\begin{array}{l}\text { Service and repair } \\
\text { items }\end{array}$ & $\begin{array}{c}\text { Number of } \\
\text { operators }\end{array}$ & Percentage & $\begin{array}{c}\text { Service and } \\
\text { repair items }\end{array}$ & $\begin{array}{c}\text { Number of } \\
\text { operators }\end{array}$ & Percentage \\
\hline Belts & 109 & 93 & Injection nozzle & 28 & 24 \\
\hline Air cleaner & 74 & 64 & Plunger & 17 & 15 \\
\hline Fuel filter & 74 & 64 & Piston ring & 6 & 5 \\
\hline Oil filter & 62 & 54 & Piston & 6 & 5 \\
\hline Changing engine & & & Connecting rod & 6 & 5 \\
\hline \& Transmission oils & 86 & 75 & Metal & 6 & 5 \\
\hline Clutch & 109 & 93 & Oil seal & 12 & 10 \\
\hline Wheel bearing & 25 & 22 & Implements & 17 & 15 \\
\hline
\end{tabular}


Table 2. Availability and distribution of repair shops in Riau Province

\begin{tabular}{|l|c|c|c|}
\hline \multirow{2}{*}{ Regencies } & \multicolumn{2}{|c|}{ Type and number of workshops } & \multirow{2}{*}{ Total } \\
\cline { 2 - 3 } & Repair shops & Welding shops & \\
\hline Kampar & 2 & 0 & 2 \\
\hline Indragiri Hulu & 0 & 2 & 2 \\
\hline Indragiri Hilir & 1 & 0 & 1 \\
\hline Rokan Hilir & 4 & 1 & 5 \\
\hline Siak & 1 & 0 & 1 \\
\hline Rokan Hulu & 1 & 0 & 1 \\
\hline Kuantan Sengingi & 0 & 0 & 0 \\
\hline Bengkalis & 1 & 0 & 1 \\
\hline Pelalawan & 0 & 3 & 3 \\
\hline Dumai & 0 & 0 & 0 \\
\hline All Riau Province & 11 & 5 & 16 \\
\hline
\end{tabular}

Source: Food Crop Services of Riau Province, 2007.

Table 3. Place of purchase and price of tractor spare parts

\begin{tabular}{|l|r|r|r|r|r|r|}
\hline \multirow{3}{*}{ Type of parts } & \multicolumn{6}{|c|}{ Purchase place } \\
\cline { 2 - 7 } & \multicolumn{2}{|c|}{$\begin{array}{c}\text { Dealer in Province } \\
\text { Capital }\end{array}$} & \multicolumn{2}{c|}{$\begin{array}{c}\text { Shops in Regency } \\
\text { Capital }\end{array}$} & \multicolumn{2}{c|}{$\begin{array}{c}\text { Local shops near or } \\
\text { within village area }\end{array}$} \\
\cline { 2 - 7 } & Percentage & $\begin{array}{c}\text { Price* } \\
\text { (Rp1000) }\end{array}$ & Percentage & $\begin{array}{c}\text { Price } \\
\text { (Rp1000) }\end{array}$ & Percentage & $\begin{array}{c}\text { Price } \\
\text { (Rp1000) }\end{array}$ \\
\hline Belts & 19 & 40 & 44 & $45(13)$ & 37 & $50(25)$ \\
\hline Nozzle & 86 & 195 & 16 & $225(15)$ & - & - \\
\hline Plunger & 86 & 275 & 16 & $315(15)$ & - & - \\
\hline Metal & 75 & 63 & 25 & $75(19)$ & - & - \\
Piston (plus ring) & 100 & 294 & & & - & - \\
Bearing & 22 & 96 & 50 & $105(20)$ & 33 & $120(25)$ \\
\hline
\end{tabular}

Sources: *) Based on list price of spare parts in dealer

Note: Values in parentheses are percentage increase in price of parts compared to dealers

Rp1000 is equivalent to about U.S. $\$ 0.118$ according to an average of exchange rate in 2005 .

Table 4. Repair process of tractor breakdown at farm level

\begin{tabular}{|c|c|c|c|}
\hline \multirow{3}{*}{ Repair category } & \multicolumn{3}{|c|}{ Repair process (\%) } \\
\hline & \multirow{2}{*}{$\begin{array}{l}\text { According to } \\
\text { Schedule }\end{array}$} & \multicolumn{2}{|c|}{ Delay } \\
\hline & & $\begin{array}{l}\text { Inadequate repair and } \\
\text { maintenance facilities* }\end{array}$ & Financial difficulty \\
\hline Minor repair & 84.2 & 10.5 & 5.3 \\
\hline Major repair & 6,7 & 60.0 & 33.3 \\
\hline
\end{tabular}

Note: $*=$ Spare parts, workshops, and mechanics. 
Table 5. Daily maintenance checks performed by the Farmers

\begin{tabular}{|l|c|l|}
\hline Maintenance checks & Number of tractors & Percentage \\
\hline Air cleaner & 15 & 24 \\
\hline Cooling water & 18 & 29 \\
\hline Bolts and nuts & 20 & 32 \\
\hline Loose or damaged parts & 22 & 35 \\
\hline Leaks & 25 & 40 \\
\hline
\end{tabular}

Table 6. Farmers' Schedule of oil service interval in equivalent hour*

\begin{tabular}{|l|c|c|c|c|}
\hline \multirow{2}{*}{ Service schedule } & \multicolumn{2}{|c|}{ Equivalent hour } & \multirow{2}{*}{$\begin{array}{c}\text { Number of } \\
\text { tractors }\end{array}$} & \multirow{2}{*}{ Percentage } \\
\cline { 2 - 3 } & Range & Average & & \\
\hline According to operator's manual & - & 100 & 6 & 10 \\
\hline Less than operator's manual & $50-90$ & 60 & 27 & 43 \\
\hline Longer than operator's manual & $105-280$ & 170 & 29 & 47 \\
\hline
\end{tabular}

Table 7. Way of storing tractors during off-season

\begin{tabular}{|l|c|c|}
\hline Storing place & Number of tractors & Percentage \\
\hline Shed & 25 & 40.3 \\
\hline Porch & 20 & 32.3 \\
\hline Outdoor & 17 & 27.4 \\
\hline
\end{tabular}

